\title{
Contribution of ICF on the functionality of individuals with chronic low back pain
}

\section{Contribuição da CIF na funcionalidade de indivíduos com lombalgia crônica}

\author{
Bárbara Cordeiro Santos', Karoleen Oswald Scharan', Mariane Benicio Fontana², Auristela Duarte de Lima Moser ${ }^{3}$
}

\begin{abstract}
Introduction: The use of the International Classification of Functioning, Disability and Health (ICF) in clinical settings has been emphasized with the objective of establishing a standardized language among professionals, as well as to collect and interpret related results to health and states related to it in different cultures from a biopsychosocial perspective. Objective: To define the functional profile of from patients with chronic low back pain based on the International Classification of functioning, disabilities and health (ICF). Method: During February-March of 2014 a functional questionnaire based on the ICF was applied for 42 adults. Results: The mean age was 47.8 ( \pm 16.9 ) years, with predominance of women $(69 \%)$. Two categories and one subcategory represented higher percentage of difficulty: Using transport (54.8\%), Household tasks (62.5\%) and Bending (69.1\%). In Environmental Factors, 50\% of the sample reported having difficulty accessing public environments. The categories of self-care domain did not show high percentage of difficulty. Conclusion: The use of the functional questionnaire was able to determine the functional profile of the subjects, contributing to subsidize interventions in a program of Back School. Approaches may be more targeted based on codes where there were greater difficulties and may be more specific to participants daily life.
\end{abstract}

Keywords: International Classification of Functioning; Disability and Health; Low Back Pain; Health Education; Physical Therapy; Health Profile.

\section{RESUMO}

Introdução: O uso da Classificação Internacional de Funcionalidade, Incapacidade e Saúde (CIF) em contextos clínicos tem sido enfatizado com os objetivos de estabelecer uma linguagem padronizada entre os profissionais, bem como para coletar e interpretar os resultados referentes à saúde e estados relacionados a ela em diferentes culturas a partir de uma perspectiva biopsicossocial. Objetivo: Traçar o perfil funcional de lombálgicos crônicos com base na Classificação Internacional de funcionalidade, Incapacidade e Saúde (CIF). Método: No período de fevereiro a maio de 2014 foi elaborado e aplicado um questionário de funcionalidade com base na CIF, em 42 participantes de um programa de Escola da Coluna. Resultados: A média de idade foi de 47.8 ( \pm 16.9 ) anos, com predomínio do sexo feminino (69\%). Duas categorias e uma subcategoria da CIF apresentaram maior dificuldade: Utilização de transporte (54.8\%), Realizar tarefas domésticas (62.5\%) e Curvar-se (69.1\%). Nos Fatores Ambientais, 50\% da amostra relatou ter dificuldade em acessar ambientes públicos. As categorias do Autocuidado não apresentaram dificuldade elevada. Conclusão: A utilização do questionário de funcionalidade foi capaz de traçar o perfil funcional dos sujeitos, contribuindo para subsidiar as intervenções em um programa de Escola da Coluna. As abordagens poderão ser mais direcionadas com base nos códigos em que houve maiores dificuldades e poderão ser mais específicas à vida cotidiana da amostra.

Palavras-chave: Classificação Internacional de Funcionalidade; Incapacidade e Saúde; Lombalgia; Educação em Saúde; Fisioterapia; Perfil de Saúde.

Corresponding Author: Auristela Duarte de Lima Moser. Rua Imaculada Conceição, 1155, Prado Velho, Zip Code: 80215-901, Curitiba (PR), Brazil. E-mail: auristela. lima@gmail.com

${ }^{3} \mathrm{PhD}$ in Engineering Production, Pontifícia Universidade Católica do Paraná (PUCPR), Curitiba (PR), Brazil.

Full list of author information is available at the end of the article.

Financial support: Coordenação de Aperfeiçoamento de Pessoal de Nível Superior (CAPES), FUNDAÇÃO ARAUCÁRIA, PUCPR.

Submission date 7 August 2015; Acceptance date 16 November 2015; Online publication date 24 November 2015 


\section{INTRODUCTION}

The use of the International Classification of Functioning, Disability and Health (ICF) in clinical settings has been emphasized with the objective to establish a standardized language among professionals to ensure quality to collect and interpret the results relating to health and states related to it in different cultures. ${ }^{(1,2)}$ The ICF covers health from a biopsychosocial perspective, because it incorporates health components at body and social levels. ${ }^{(1)}$

The classification is divided into two parts, the first referring to the functional components containing "functions and structures of the body" and "activities and participation", and the second refers to the components of contextual factors, including the "environmental and personal factors". (2) Each component consists of various areas or chapters which include more specific items. ${ }^{(2)}$ Within 30 existing domains, there are 1.454 categories and subcategories related to these items. ${ }^{(2)}$ Each category and subcategory are represented by a code, and when added to a qualifier specifies the size of the feature or inability of a person. ${ }^{(2)}$

Due to the scope of ICF, has been created checklists, which are collections of the most important categories for attention to a person ${ }^{(2)}$ and core sets, which are sets of specific categories for a given disease, in order to facilitate their application. $(3,4)$ Another way to apply the ICF is through the selection of categories considered relevant to research specific needs grounded on clinical experience of professionals. ${ }^{(5)}$ The World Health Organization (WHO) suggests using the classification in different environments and contexts in order to contribute for further revision of ICF and to refine the categories selected in the core sets and checklists. ${ }^{(5,6)}$

It is known that chronic low back pain is a debilitating condition that affects world's population, mainly in the productive phase. ${ }^{(7)}$ Pain is one of the main complaints, however, other physical, psychological, social and environmental aspects have also been strongly associated with disability. ${ }^{(8)}$ A number of approaches have been applied to intervene in these respects. ${ }^{(9)}$ Among them, the Back School has stood out through its theoretical and practical approach, the effectiveness of the reduction of pain conditions and improving function in patients with chronic low back pain. ${ }^{(9,10)}$ In addition, patient education is a viable, low cost, favoring the interaction between patient and therapist enhancing the functional health. ${ }^{(9,11,12)}$

The insertion of the ICF along with programs like the Back School could contribute to support prevention and health promotion. The information provided by application of ICF possible to know the functional profile and thus improve the approach used by developing more targeted to everyday life interventions. ${ }^{(13)}$ The objective of this study was to outline the profile of participants in a Back School program based in ICF.

\section{METHODS}

The present study was quantitative cross-section with adult volunteers. The inclusion criteria were: male and female; with low back pain for more than three months; minimum age of 18 years; clinical diagnosis made by a specialist. As for the exclusion criteria were: pregnancy; fractures in the spine; have undergone surgery for less than six months; serious osteoporosis and/or tumors in the spine; be away from work for low back pain; having been diagnosed with fibromyalgia; be in some other physical therapy.

The study was conducted among a Back School Program implemented for five years at a private university in the city of Curitiba. The research project was approved by the Research Ethics Committee with humans PUCPR under number 24.140. In the period from February to May 2014, attended by 48 individuals, of which 6 were excluded after assessment, for submitting one or more exclusion criteria. The other subjects were divided into five groups to participate in interventions for 10 weekly meetings lasting an hour each. For purposes of this study, only the data from the initial assessment were used.

Physical therapy evaluation was performed, applied to visual analog scale (VAS) and used a functional questionnaire prepared from the consensus of the researchers, based on the literature, ICF and experience with Back School in order to verify the functionality of the participants.

Initially the SF-36 and Roland-Morris Questionnaire (RMQ) were selected to support the classification. After a pilot study opted for the selection and application of categories and subcategories that represent the content covered in the questionnaires due to non-equivalence scales. The pilot study data were incorporated into the results of the general assembly for discussion. To the pilot study data set itself the qualifier 8 in situations where it was difficult to quantify from the questionnaires.

After application of the instruments collected data were organized in an Excel table containing sociodemographic data, the VAS score and the codes generated by the ICF. Statistical analysis was used IBM SPSS 20. The results obtained in the study were expressed as frequencies and percentages or means and standard deviations.

\section{RESULTS}

The sociodemographic characteristics of the 42 subjects tested are shown in Table 1.

The study included subjects $18-78$ years (mean \pm standard deviation $=47.8 \pm 16.9$ years), with predominance of females (69\%). In the sample, $69 \%$ are Catholic and $47.6 \%$ are married. Regarding the number of children, 13 (31\%) subjects reported to do not have children and others have 1 to 5 .

Based on height and weight was calculated body mass index (BMI), which expressed in overweight sample (mean $\pm S D=26.3 \pm 5.3 \mathrm{~kg} / \mathrm{m}^{2}$ ), with a minimum of $16.9 \mathrm{~kg} / \mathrm{m}^{2}$ and up to $41.9 \mathrm{~kg} / \mathrm{m}^{2}$. With regard to physical activity, $54.8 \%$ 
Table 1. Socio-demographic characteristics.

\begin{tabular}{|c|c|}
\hline VARIÁBLES & RESULTS (\%) \\
\hline AGE (YEARS) & $47.8 \pm 16.9$ \\
\hline GENDER - FEMALE & $29(69)$ \\
\hline BMI & $26.3 \pm 5.3$ \\
\hline \multicolumn{2}{|l|}{ MARITAL STATUS } \\
\hline SINGLE & $12(28.6)$ \\
\hline MARRIED & $20(47.6)$ \\
\hline DIVORCED & $3(7.1)$ \\
\hline WIDOWED & $5(11.9)$ \\
\hline STABLE UNION & $2(4.8)$ \\
\hline \multicolumn{2}{|l|}{ RELIGIOUS BELIEF } \\
\hline CATHOLIC & $29(69)$ \\
\hline EVANGELICAL & $8(19)$ \\
\hline SPIRITISM & $3(7.1)$ \\
\hline OTHERS & $2(4.8)$ \\
\hline \multicolumn{2}{|l|}{ NUMBER OF CHILD } \\
\hline 0 & $13(31)$ \\
\hline 1 & $7(16.7)$ \\
\hline 2 & $10(23.8)$ \\
\hline 3 & $10(23.8)$ \\
\hline$\geq 4$ & $2(4.8)$ \\
\hline PHYSICAL ACTIVITY PRACTICE - YES & $19(45.2)$ \\
\hline SPORTS PRACTICE- YES & $31(73.8)$ \\
\hline \multicolumn{2}{|l|}{ EDUCATION } \\
\hline INCOMPLETE PRIMARY EDUCATION & $4(9.5)$ \\
\hline COMPLETE PRIMARY EDUCATION & 5 (11.9) \\
\hline INCOMPLETE HIGH SCHOOL & $2(4.8)$ \\
\hline COMPLETE HIGH SCHOOL & $8(19)$ \\
\hline INCOMPLETE HIGHER EDUCATION & 5 (11.9) \\
\hline COMPLETE HIGHER EDUCATION & $18(42.9)$ \\
\hline \multicolumn{2}{|l|}{ OCCUPATION } \\
\hline REMUNERATIVE EMPLOYMENT & $18(42.9)$ \\
\hline STUDENT & $7(16.7)$ \\
\hline HOUSEWIFELY & $6(14.3)$ \\
\hline RETIRED & $8(19)$ \\
\hline AWAY & $2(4.8)$ \\
\hline UNEMPLOYED & $1(2.4)$ \\
\hline \multicolumn{2}{|l|}{ FAMILY INCOME (MINIMUM SALARY) } \\
\hline 0 & $14(23.7)$ \\
\hline 1 to 2 & $21(35.6)$ \\
\hline 3 to 4 & $24(40.7)$ \\
\hline$\geq 5$ & $9(21.4)$ \\
\hline
\end{tabular}

Note: Results expressed as means \pm standard deviation or frequency (percentage). of subjects did not practice any sport. As for the $30 \%$ who practiced, they performed 2, 3 or 5 times a week. For the leisure $73.8 \%$ of the subjects reported having leisure activity, such as reading, crafts and tours. The results of the questionnaire functionality are expressed in Tables 1 and 2 .

Table 2 presents the codes and questions concerning the components "body functions" and "activities and participation". In the right column are inserted into the "Qualifiers ICF" represented by the numbers 0, 1, 2, 3, 4, 8 and 9. Qualifiers 1, 2, 3 and 4 indicate progressive levels of disability, being 1 mild disability, 2 moderate, 3 severe and 4 complete. Qualifiers 0 and 9 respectively indicate no difficulty and not applicable. The qualifier 8 regards to the pilot study information collected. In the subcategory Urinary continence (b6202) within the category Urinary functions (b620), 69\% of subjects had no difficulty in functions related to the control of urination. The other $26.2 \%$ were distributed with mild, moderate and severe difficulty, and $4.8 \%$ of the subjects were tagged with the qualifier 8 . In the category Sexual functions (b640), $64.3 \%$ of subjects reported no difficulties for sexual activity. The other $21.4 \%$ of the sample corresponded to mild, moderate and severe qualifiers, and $7.1 \%$ of the subjects reported no sexual activity.

The category Moving around using equipment (d465), contemplated in the Walking and moving section, revealed that subjects did not need help to walk. Regarding to the displacement using transport, Using transportation (d470), $45.2 \%$ reported no difficulty to be passengers. However, $54.8 \%$ of subjects reported some difficulty, of these, $28.6 \%$ considered it as moderate. This difficulty has been reported mainly in the act of entering or exiting the vehicle, or the fact stay for long periods inside. In the category Driving (d475) the percentage of subjects who reported no difficulty driving a vehicle was equal to the previous category $(45.2 \%)$, and $26.6 \%$ were distributed among the qualifiers 1, 2, 3 and 4 . There were subjects that did not drive $(23.8 \%)$ and $4.8 \%$ of the sample was classified with qualifier 8.

Regarding the self-care domain in the category Washing oneself (d510), $69 \%$ of the sample presented no difficulty for this action, while $14.4 \%$ had difficulty in varying degrees. Similar results occurred in the category Dressing (d540), with $64.3 \%$ of subjects without difficulty and $16.7 \%$ distributed among the qualifiers 1,2 and 3 . In the code $d 5202$, referring to the sub-category Caring for hair, $81 \%$ of the sample reported no difficulty to do the job and $19 \%$ had mild, moderate and complete difficulties. In the mobility section, the subcategory Bending (d4105) showed more than half of the subjects (69.1\%) unable to execute the movement. This difficulty has been more frequent in moderate degree, which represents $26.2 \%$ of the sample. There were also slight difficulty reported to $(14.3 \%)$, severe $(11.9 \%)$ and complete $(16.7 \%)$.

In the category related with the Toileting, the subcategory d5300 revealed that $78.6 \%$ of the subjects did not have 
difficulties in regulating urination. In the code $\mathrm{d} 5301$, regarding the regulating defecation also prevailed a higher frequency of subjects (66.6\%) who reported no difficulty. However, among the subjects who reported having difficulty, $16.7 \%$ classified it as moderate.

Regarding to Maintaining one's health (d5702), it was asked whether there was some difficulty in caring for oneself, being aware of the need and doing what is required to look after one's health, following medical and other health advice. More than half of the subjects $(64.3 \%$ ) reported no difficulty in this item. The other half reported mild or moderate difficulty in $19 \%$ and $7.1 \%$ of the sample, respectively. This difficulty was justified by the lack of time and not for lack of understanding of the advices.

Regarding activities related to household chores such as preparing meals (d630), 66.7\% of subjects did not present difficulty in planning, organizing, cooking and serving meals. In the category Doing housework (d640), the sample appeared divided between qualifying 1 and 8 , with respectively $26.8 \%$ and $35.7 \%$. Regarding the category of Remunerative employment (d850), $14.3 \%$ of participants reported no difficulty to participate in all aspects of work. For each of the qualifiers 1, 2 and 3 was $7.1 \%$ of difficulty. The qualifier 8 was marked by $11.9 \%$ of participants and the qualifier 9 in $52.4 \%$, as were students, home retired and unemployed.

Table 3 describes the categories for the domain "environmental factors". For this component are allocated qualifiers from +1 to +4 to represent a facilitator, and .1 to .4 a barrier. This scale is a progressive intensity that the person experiences an environmental factor barrier or facilitator. The qualifiers 0,8 and 9 remained the same meaning mentioned in table 2.

Table 2. Functions of the Body and Activities and Participation.

\begin{tabular}{|c|c|c|c|c|c|c|c|c|c|}
\hline \multirow{2}{*}{ Category } & \multirow{2}{*}{$\begin{array}{c}\text { Category description } \\
\text { Functionality and Disability }\end{array}$} & \multicolumn{7}{|c|}{ ICF qualifiers } & \multirow{2}{*}{$\%$} \\
\hline & & 0 & 1 & 2 & 3 & 4 & 8 & 9 & \\
\hline b6202 & Urinary continence & 29 & 3 & 6 & 2 & 0 & 2 & 0 & 31 \\
\hline b640 & Sexual functions & 27 & 4 & 3 & 2 & 0 & 3 & 3 & 27 \\
\hline d465 & Moving around using equipment & 42 & 0 & 0 & 0 & 0 & 0 & 0 & 0 \\
\hline $\mathrm{d} 470$ & Using transportation & 19 & 9 & 12 & 1 & 1 & 0 & 0 & 54.8 \\
\hline d475 & Driving & 19 & 5 & 4 & 1 & 1 & 2 & 10 & 31 \\
\hline d510 & Washing oneself & 29 & 2 & 2 & 1 & 1 & 7 & 0 & 31 \\
\hline d5202 & Caring for hair & 34 & 4 & 2 & 0 & 2 & 0 & 0 & 19.1 \\
\hline d4105 & Bending & 12 & 6 & 11 & 5 & 7 & 0 & 1 & 83.4 \\
\hline d5300 & Regulating urination & 33 & 5 & 2 & 2 & 0 & 0 & 0 & 21.5 \\
\hline d5301 & Regulating defecation & 28 & 5 & 7 & 1 & 0 & 1 & 0 & 33.4 \\
\hline d540 & Dressing & 27 & 2 & 4 & 1 & 0 & 8 & 0 & 35.7 \\
\hline d5702 & Maintaining one's health & 27 & 8 & 3 & 0 & 1 & 3 & 0 & 33.3 \\
\hline d630 & Preparing meals & 28 & 7 & 4 & 2 & 0 & 0 & 1 & 14.3 \\
\hline d640 & Doing housework & 11 & 2 & 9 & 2 & 2 & 16 & 0 & 72.4 \\
\hline d850 & Remunerative employment & 6 & 3 & 3 & 3 & 0 & 5 & 22 & 33.2 \\
\hline
\end{tabular}

Note: results described by frequency (percentage).

Table 3. Environmental Factors.

\begin{tabular}{|c|c|c|c|c|c|c|c|c|c|c|c|c|c|}
\hline \multirow{3}{*}{ Category } & Category description & \multicolumn{11}{|c|}{ ICF qualifiers } & \multirow{3}{*}{$\%$} \\
\hline & Environmental factors & \multicolumn{4}{|c|}{ Barrier (.) } & \multicolumn{4}{|c|}{ Facilitator (+) } & \multirow{2}{*}{$\frac{(0)}{0}$} & \multicolumn{2}{|c|}{$\begin{array}{l}\text { Not Specified } \\
\text { (8) or not } \\
\text { applicable (9) }\end{array}$} & \\
\hline & Contextual Factors & 1 & 2 & 3 & 4 & 1 & 2 & 3 & 4 & & 8 & 9 & \\
\hline e150 & $\begin{array}{l}\text { Design, construction and building products and technology } \\
\text { of buildings for public use }\end{array}$ & 12 & 7 & 1 & 1 & 0 & 0 & 0 & 0 & 21 & 0 & 0 & 50 \\
\hline e155 & $\begin{array}{l}\text { Design, construction and building products and technology } \\
\text { of buildings for private use }\end{array}$ & 7 & 5 & 0 & 2 & 0 & 0 & 0 & 0 & 28 & 0 & 0 & 33.4 \\
\hline
\end{tabular}

Note: results described by frequency (percentage). 
The first category is Design, construction and building products and technology of buildings for public use (e150). For this category was formulated a question regarding the presence or absence of difficulty to use / access public places. Half of the subjects (50\%) reported no difficulties in accessing such environments. Since the other half was divided among qualifiers 1, 2, 3 and 4 with prevalence qualifier 1 (28.6\%), followed by the qualifier $2(16.7 \%)$. The second category corresponds to private use (e155). In the sample $66.7 \%$ of subjects reported no difficulty with products and technology that constitute both indoor and outdoor environment. However, for those who found it difficult, there was a higher percentage for the slight difficulty (16.7\%).

The evaluation of VAS had an average of $5.55( \pm 2.3)$, with a minimum of 0 and maximum of 10 , whichever moderate pain in the sample.

\section{DISCUSSION}

The set of selected categories was able to trace a functional profile of the participants in a Back School. To our knowledge, it is the first time that ICF was applied in a educational-theoretical approach. This assisted assessments and permitted to use the results to improve interventions.

The prevalence of women and participants with an average age of about 47 years corroborates previous studies obtained with low back pain patients and related to ICF. ${ }^{(14,15)}$ The highest incidence of pain in the economically productive phase and with increasing age confirm the findings of this study. ${ }^{(8,12)}$

Regarding the mean $\mathrm{BMI}$, the sample were in a overweight condition, confirming the reality of the Brazilian population. ${ }^{(16)}$ Moreover, the results are similar to those of other studies of low back pain. ${ }^{(15,17)}$ Low back pain has been linked to overweight due to a sum of structural, metabolic and behavioral factors such as low practice of physical activity. ${ }^{(17-19)}$ The change in weight and low practice of physical activity remind us of the interdependence between the components "body functions" and "activities and participation" of ICF, being pronounced in chronic low back pain subjects impacting on quality of life. ${ }^{(17)}$

It is noticed that fewer participants reported engaging in physical activities than leisure activities. The main reasons for not carrying out a physical activity were justified by physical limitations, pain and lack of courage. It is possible to hypothesize that the participants on this study compensate for low physical activity with some leisure activity, considering that leisure may require less effort to exercise.

The average years of study sample were 12 years, which corresponds to complete high school. Studies show that education is directly related to self-care, the understanding and practice of guidance on health, for example, the higher the education, the better self-care. ${ }^{(20,21)}$ This information corroborates the extent of the sample instruction and the results of the ICF categories related to self-care.

Self-care attitudes and interpersonal relationships are linked and the environment in which the individual is inserted. More developed places enable greater self-service, as they are offered services to contemporaries levels, such as education, health, transportation, communication. ${ }^{(22)}$ Therefore the importance of providing this education service to people in vulnerable contexts, and increase the potential for self-care of these individuals, treatment could become more comprehensive, reaching audiences with different levels of educational background. This idea shows the importance of the incorporation of the biopsychosocial model recommended by WHO. ${ }^{(2)}$

Regarding the functional profile itself, the Bending subcategory was chosen in this study because there is a common account of the participants of the Back School to perform this action. In this subcategory, $69.1 \%$ of the sample reported difficulty. Riberto et al. ${ }^{(15)}$ (2011), applying the ICF core set for low back pain obtained in the sample, $51.7 \%$ of difficulty in the category referring to change the basic position of the body, which is a broader category. By using a broader category, ICF is not able to report on what specific position there is some difficulty. ${ }^{(15,23,24)}$ Thus, it emphasizes the importance of using more specific codes as in the case of this study for, besides characterizing a sample and/or population get results that direct the therapeutic planning.

In this study, the subcategories related to Regulating urination and defecation showed low difficulty in these items, $21.4 \%$ and $33.4 \%$. By applying the most comprehensive category, related to the excretion process, two studies ${ }^{(14,15)}$ using the ICF core set for low back pain patients had, respectively, $12 \%$ and $20.7 \%$ of the sample with difficulty. From the findings it can be inferred that for this issue, the option of using the most comprehensive subcategory or category does not interfere in the answer, because the description of the activity is the same. Still, it is difficult to know that this issue can be addressed in the Back School.

The category that refers to sexual functions showed low percentage of difficulty, with $21.5 \%$ of the sample. This result is similar to the result of Riberto et al. ${ }^{(15)}$ (2011), with $22.2 \%$. There was also low difficulty in the category related to urinary functions (31\%) agreeing with other studies. ${ }^{(14,15)}$ Although the results are similar, there is need for further studies to raise data on sexual and urinary functions in low back pain patients.

In this study, the category Moving around using equipment presented unanimously in the absence of difficulty. It is believed that the use of orthoses is associated with more severe cases of low back pain, which does not apply to the present study sample. In the category of Transportation, more than half of the sample reported difficulties to come and go or stay long periods in the vehicle. These reports may be related to biomechanical and ergonomic functions, showing again the interaction between all components of the ICF.

In the category Doing housework $62.5 \%$ of the sample had difficulty, as in other studies. ${ }^{(14,15)}$ This difficulty may be justified by the higher frequency of economically inactive women. In this sense, health education programs related to 
chronic low back pain should prioritize the information on the operation of the column in the household and seek ways to address the issue of experiential mode. ${ }^{(25,26)}$

In the present study the results of the component "environmental factors" claim that interference barriers functionality of participants in public and private environments, being higher in public. It is assumed that domestic environments could be more adapted than the public spaces, favoring functionality. It is important to emphasize the importance of intervening in "environmental factors" so as to enhance the functional performance. ${ }^{(13)}$

As regards the ICF, public policies based on this classification, such as the National Policy for Functional Health, have been developed to assess, guide and treat individuals in a broader way. However, the applicability of these policies is still in its beginning, there is no clarity on the methodology for use of the classification in health services and not for the analysis of the results from its application. Using the ICF could contribute to improve the treatment of diseases, understanding the factors that may be associated with them and prevent them. (2) In addition, their use could reduce costs associated with dealing with hard technologies, ${ }^{(27)}$ spending relating to social security and demand for specific professionals, since the emphasis of the ICF is in primary care. ${ }^{(11)}$

\section{CONCLUSION}

It was possible to identify the functional profile of subjects of a Back School incorporating the ICF as an evaluation tool. Its application shows that it is possible to generate a code supporting both assessments and interventions. Still, the ICF categories with greater relevance concentrated on activities and participation and environmental factors, allowing for reflection on how to intervene in these components to improve the functional status of the participants. The preliminary applications show the need to improve the selection of domains as a source of information to define the approach and content improvement thereof. The use of ICF in an educational therapeutic environment could collect in order to use data comparing different populations.

\section{AUTHORS CONTRIBUTION}

$B C S, K O S, M B F, A D L M:$ Project elaboration, data collection, data analysis, writing; Data analysis, writing; Project and article orientation and writing review.

\section{COMPETING INTERESTS}

The authors declare no conflicts of interest.

\section{AUTHOR DETAILS}

${ }^{1}$ Master's degree student in Health Technology, Pontifícia Universidade Católica do Paraná (PUCPR), Curitiba (PR), Brazil. ${ }^{2}$ Master degree in Health Technology, Pontifícia Universidade Católica do Paraná (PUCPR), Curitiba (PR), Brazil.

\section{REFERENCES}

1. Farias N, Buchalla CM. A classificação internacional de funcionalidade, incapacidade e saúde da organização mundial da saúde: conceitos, usos e perspectivas. Rev. bras. epidemiol. 2005;8:187-93.

2. Organização Mundial da Saúde (OMS). CIF: Classificação Internacional de Funcionalidade, Incapacidade e Saúde. In: Saúde OMd, editor. 1 ed. São Paulo: Editora da Universidade de São Paulo EDUSP; 2003. p. 328.

3. Cieza A, Ewert T, Ustun TB, Chatterji S, Kostanjsek N, Stucki G. Development of ICF Core Sets for patients with chronic conditions. J Rehabil Med. 2004:9-11.

4. Cieza A, Stucki G, Weigl M, Disler P, Jackel W, van der Linden S, et al. ICF Core Sets for low back pain. J Rehabil Med. 2004;36(0):69-74.

5. Castaneda L, Castro SSd. Brazilian publications on the International Classification of Functioning. Acta Fisiátr. 2013;20(1):29-36.

6. Selb M, Escorpizo R, Kostanjsek N, Stucki G, Ustün B, Cieza A. A guide on how to develop an international classification of functioning, disability and health core set. Eur J Phys Rehabil Med. 2015 Feb;51(1):105-17.

7. Cecin HA, Molinar MHC, Lopes MAB, Morickochi M, Freire M, Bichuetti JAN. Dor lombar e trabalho: um estudo sobre a prevalencia de lombalgia e lombociatalgia em diferentes grupos ocupacionais. Rev. Bras. Reumatol. 1991;31(2):50-6.

8. Andersson GBJ. Epidemiological features of chronic low-back pain. The lancet. 1999;354(9178):581-5.

9. Andrade SCd, Araújo AGRd, Vilar MJP. Back School: historical revision and its application in chronic low back pain. Rev. Bras. Reumatol. 2005;45(4):224-8.

10. Noll M, Vieira A, Darski C, Candotti CT. Escolas posturais desenvolvidas no Brasil: revisão sobre os instrumentos de avaliação, as metodologias de intervenção e seus resultados. Rev Bras Reumatol. 2013;54(1):51-8.

11. Ministério da Saúde. Política Nacional de Saúde Funcional: Construindo mais saúde para a população. Brasília, 2011.

12. Moser AD, Scharan KO, Pereira PA, Passini C. Escola da coluna associada a estabilizacão segmentar na lombalgia mecânico-degenerativa. Ter Man. 2012;10(50):364-73.

13. Araujo ES. Uso da CIF no SUS: A Experiência no município de Barueri-SP. Revista CIF Brasil. 2014;(1):10-7.

14. Bautz-Holter E, Sveen U, Cieza A, Geyh S, Røe C. Does the International Classification of Functioning, Disability and Health (ICF) core set for low back pain cover the patients' problems? A cross-sectional contentvalidity study with a Norwegian population. Eur J Phys Rehabil Med. 2008;44(4):387-97.

15. Riberto M, Chiappetta LM, Lopes KAT, Battistella LR. A experiência brasileira com o core set da classificação internacional de funcionalidade, incapacidade e saúde para lombalgia. Coluna/Columna. 2011;10(2):121-6.

16. Ministério da Saúde. VIGITEL Brasil 2013: Vigilância de fatores de risco e proteção para doenças crônicas por inquérito telefônico. Brasília, 2014.

17. Smuck M, Kao M-CJ, Brar N, Martinez-Ith A, Choi J, Tomkins-Lane CC. Does physical activity influence the relationship between low back pain and obesity? Spine J. 2014;14(2):209-16.

18. Mendonça CP, dos Anjos LA. Aspectos das práticas alimentares e da atividade física como determinantes do crescimento do sobrepeso/ obesidade no Brasil Dietary and physical activity factors as determinants of the increase. Cad Saúde Pública. 2004;20(3):698-709.

19. DiasThomaz PM, Costa THMd, Silva EFd, Halla PC. Fatores associados à atividade física em adultos, Brasília, DF. Rev Saude Publica. 2010;44(5):894900.

20. Barbui EC, Cocco MIM. Conhecimento do cliente diabético em relação aos cuidados com os pés. Rev Esc Enferm USP. 2002;36(1):97-103.

21. Comissão Nacional sobre determinantes sociais da saúde (CNDSS). As causas sociais das iniquidades em saúde no Brasil. Rio de Janeiro: Fiocruz; 2008. 
22. Ergün S, Conk Z. Effect of individualized education efforts by a nurse to increase self-care capacity in adoscent. Acta paul. enferm. 2011;24(6):821-7.

23. Grill E, Mansmann U, Cieza A, Stucki G. Assessing observer agreement when describing and classifying functioning with the International Classification of Functioning, Disability and Health. J Rehabil Med. 2007;39(1):71-6.

24. Hilfiker R, Obrist S, Christen G, Lorenz T, Cieza A. The use of the comprehensive International Classification of Functioning, Disability and
Health Core Set for low back pain in clinical practice: a reliability study. Physiother Res Int. 2009;14(3):147-66.

25. Nordin M. Back pain: lessons from patient education. Patient education and counseling. 1995;26(1):67-70.

26. DelPrette A, DelPrette ZAP. Psicologia das relações interpessoais: vivências para o trabalho em grupo: Ed. Vozes; 2001.

27. Onocko R, Merhy EE. Agir em Saúde: um desafio para o público: Hucitec; 1997. $385 \mathrm{p}$. 